\title{
Characterization of edible films of Swartzia burchelli phosphated starches and development of coatings for post-harvest application to cherry tomatoes
}

\author{
Caracterização de filmes comestíveis de amidos fosfatados da \\ Swartzia burchelli e elaboração de coberturas para aplicação pós- \\ colheita em tomate cereja
}

\author{
Millene Aparecida Gomes ${ }^{1 *}$; Diego Palmiro RamirezAscheri² ${ }^{2}$ André José de Campos ${ }^{2}$
}

\begin{abstract}
The market demand for corn starch and cassava continues to increase because of their use in edible applications, their biodegradable nature, and other appealing properties. As a result, there is a need to identify alternative starch sources, for example, the seeds of S. burchelli, with the potential to be modified for use in post-harvest applications. Therefore, this study aimed to develop and characterize edible films based on the starch phosphates of the seeds of $S$. burchelli, with the specific aim to apply these starches to cherry tomatoes for post-harvest conservation. After extraction, the starch was phosphorylated with sodium tripolyphosphate (STP) in different concentrations and times according to a $2 \times 2$ factorial design with additional treatment (native starch). After modification, the starch phosphates were selected for the preparation of edible films using glycerol as a plasticizer, in proportions of 5, 10, 15 and 20\% for each selected starch. The films were measured for thickness, permeability to water vapor and solubility in water. According to their permeability values, 4 films were selected for application in the coverage of cherry tomatoes. The conservation of cherry tomatoes with and without coverage was studied over 8 evaluation times (up to 21 days) at $10 \pm 2{ }^{\circ} \mathrm{C}$ and $80 \pm 5 \%$ relative humidity. The weight loss, soluble solids, titratable acidity, maturation index, and firmness were measured every 3 days during storage. The starch phosphates showed a phosphorus content within that established by standards, such that the resulting films are acceptable for use in food for human consumption. The edible films presented with an acceptable appearance and without the development of cracks. The concentration of glycerol and the type of starch influenced the characteristics of the films, increasing the permeability and reducing the water solubility of the various edible films. The best result obtained regarding the conservation of cherry tomatoes was observed for fruits with edible coatings of greater permeability to water vapor; such fruits exhibited only a slight decline in firmness during storage compared with the control. It can be concluded that the modification performed on the starch and the glycerol concentration positively influenced the properties of the edible films, allowing for optimal use in post-harvest applications. Similarly, the edible coatings conferred better appearance to the fruits, maintaining their maturation index and firmness during the experimental period and providing better post-harvest storage conditions for the cherry tomatoes.
\end{abstract}

Key words: Swartzia burchelli. Tropical fruits. Modified starch. Biodegradable films. Starch technology.

\footnotetext{
${ }^{1}$ M.e em Engenharia Agrícola, Universidade Estadual de Goiás, UEG, Anápolis, GO, Brasil. E-mail: millenegomes@live.com.pt

${ }^{2}$ Profs., UEG, Anápolis, GO, Brasil. E-mail: ascheridpr@gmail.com; andre.jose@ueg.br

* Author for correspondence
} 


\section{Resumo}

Amidos de milho e mandioca estão sendo cada vez mais procurados no mercado devido à sua alta demanda para fins comestíveis, produtos biodegradáveis e outros. Devido a essa demanda, há necessidade da busca de outras fontes amiláceas, por exemplo, de sementes da $S$. burchelli, e sua modificação para aplicação em pós-colheita. Por esse motivo, o presente trabalho teve por objetivo elaborar e caracterizar filmes comestíveis a base de amidos fosfatados da semente de $S$. burchelli visando sua aplicação na conservação pós-colheita de tomate cereja. Após a extração, o amido foi fosfatado com tripolifosfato de sódio (TPS) em diferentes concentrações e tempos combinados, de acordo com um planejamento Fatorial $2^{2} \mathrm{com}$ tratamento adicional (amido nativo). Após a modificação, amidos fosfatados foram selecionados para a elaboração dos filmes comestíveis utilizando o glicerol como plastificante, em proporções de 5, 10, 15 e 20\% para cada amido selecionado. No caso dos filmes foram medidos a espessura, permeabilidade ao vapor de água e solubilidade em água. De acordo com o valor de sua permeabilidade, quatro filmes foram selecionados para aplicação em cobertura de tomates cereja. A conservação dos tomates cereja com e sem cobertura foram estudados em oito tempos de avaliação até 21 dias a $10 \pm 2{ }^{\circ} \mathrm{C}$ e $80 \pm 5 \%$ de umidade relativa. A perda de massa, sólidos solúveis, acidez titulável, índice de maturação e firmeza foram medidas a cada três dias no armazenamento. Os amidos fosfatados apresentaram teor de fósforo dentro do estabelecido pela legislação, podendo ser utilizados em alimentos para consumo humano. Os filmes comestíveis apresentaram-se com boa aparência e sem fissuras. A concentração de glicerol e tipo de amido influenciaram nas características dos filmes, aumentando a permeabilidade e reduzindo a solubilidade em água dos filmes comestíveis elaborados. $\mathrm{O}$ melhor resultado entre os obtidos da conservação dos tomates cereja foi observado nos frutos com cobertura comestível de maior permeabilidade ao vapor de água, pois, apresentaram ligeiras quedas de firmeza durante o armazenamento em comparação ao controle. Pode-se concluir que a modificação do amido e a concentração de glicerol influenciam positivamente nas propriedades dos filmes comestíveis, possibilitando seu melhor aproveitamento na pós-colheita. Da mesma forma, as coberturas comestíveis conferem melhor aparência aos frutos, mantendo o índice de maturação e firmeza durante o período experimental, propiciando melhores condições de armazenamento pós-colheita do tomate cereja.

Palavras-chave: Swartzia burchelli. Frutas tropicais. Amidos modificados. Filmes biodegradáveis. Tecnologia de amidos.

\section{Introduction}

Starch is an abundant molecule in nature. This renewable and biodegradable carbohydrate can easily be extracted from roots, tubers, and seeds. As a result, it is considering a low-cost biopolymer and plays an important role in agribusiness; in addition, starch is currently one of the most-studied and mostresearched carbohydrate sources in the production of biodegradable films (MOJOVIĆ et al., 2006; LATNER et al., 2006; PRIELER; FISCHER, 2009; ALBERTI et al., 2015). The market demand for corn and cassava starches continues to increase due to their use in edible applications, the production of biofuel and biodegradable plastics for soil cover in farming (KASIRAJAN; NGOUAJIO, 2012), as well as their use in edible films and coatings that can be applied to fruits and seeds (BOURTOOM, 2008; DHANAPAL et al., 2012).
However, the use of these conventional starches in the production of non-foodstuffs increases their cost and generates competition for these resources. For this reason, new sources of starch for human consumption are currently being sought. Swartzia burchelli, a legume of the Brazilian Cerrado (savannah), popularly known in Brazil as banhade-galinha, pacová de macaco, jacarandá-banana, jacarandá-de-sangue, and banana-de-papagaio (MANSANO, 2002), bears fruit with large starchcontaining seeds. To date, no studies on the starch of this fruit and its chemical modification via phosphorylation with sodium tripolyphosphate (STP) have been reported.

After modification, the new properties exhibited by a starch phosphate may offer advantages for the development of filmogenic solutions used in the production of edible coatings and films. 
The addition of a plasticizer such as glycerol increases the elasticity of the film, improving its overall mechanical properties and reducing the film's natural tendency toward brittle behavior (BERGO et al., 2010; KHWALDIA et al., 2010; VICENTINO et al., 2011). Henrique et al. (2008) showed that in addition to facilitating cassava starch gelatinization, modification does not require heating for the production of edible films, thereby reducing energy intake and production time. The resulting edible films also tend to exhibit good water vapor permeability characteristics.

As coatings, modified starches enhance fruit shine, making them more attractive to consumers without interfering with their sensory properties, and aid in fruit preservation and quality maintenance, increasing the shelf life of fruits. Alves et al. (2011) studied the quality of strawberries wrapped with edible antimicrobial coatings based on different sources of starch and concluded that the coatings, mainly those formulated based on cassava and modified starch, exhibited the best visual results when applied to these fruits. In addition, no sensory differences were found among the treatments, confirming that the use of different coatings contributed toward the maintenance of strawberry quality during the storage period, without altering their sensory characteristics.

The objective of the present study was to develop and characterize edible films based on native and phosphated starches of $S$. burchelli seeds, with the goal of applying these starches to cherry tomatoes to increase their post-harvest conservation.

\section{Materials and Methods}

The experiment was developed and conducted at the laboratories of Agricultural Engineering and Chemistry of the University Unit of Exact and Technological Sciences of the State University of Goiás (Universidade Estadual de Goiás) located in Anápolis, Goiás (GO), Brazil.

\section{Obtaining the raw material}

S. burchelli fruits were harvested in October 2012 from healthy plants in the Goiás Cerrado biome of the municipality of Porangatu (GO), located at $13^{\circ} 26^{\prime} 27^{\prime}$ 'S latitude, 49 $08^{\prime} 55^{\prime \prime} \mathrm{W}$ longitude and an altitude of $396 \mathrm{~m}$. Mature, whole, and healthy fruits were selected. After selection, the fruits were washed under running water and peeled using a stainless steel knife; then, the seeds were separated from the pulp. From the 500 fruits used in the study, the total seed mass obtained was $3.600 \mathrm{~g}$.

The cherry tomatoes used in the experiment were harvested from Formiga Farm, located in the municipality of Anápolis (GO) at $16^{\circ} 17^{\prime} 10^{\prime \prime S}$ latitude, 48 $52^{\prime}$ '9" $\mathrm{W}$ longitude and an altitude of $960 \mathrm{~m}$. Ripe fruits with no cracks and uniform size, ranging from 2 to $3 \mathrm{~cm}$ in equatorial diameter, were used. The fruits were washed under running water and then immersed in sodium hypochlorite solution

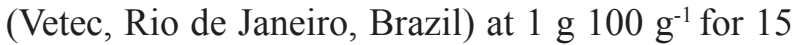
minutes; the fruits were then left to dry at room temperature.

\section{Starch extraction}

The starch was extracted from the $S$. burchelli seeds by grinding in a knife mill (Tecnal, Piracicaba, Brazil), using a $1-\mathrm{mm}$ sieve and abundant water to avoid heating the samples. The milky phase that contains the starch was separated from the fibrous mass using cheese cloth. The starch was separated from the milky phase by sieving and successive decantations using steel sieves (Bertel, Caieiras, Brazil) with 250 to $75 \mu \mathrm{m}$ fine mesh; then, the decanted starch was vacuum-filtered and dried in a forced-air oven (Marconi, Piracicaba, Brazil) at $45{ }^{\circ} \mathrm{C}$ to constant weight. The obtained starch, designated S. burchelli native starch (SBNS), was stored in glass jars with airtight lids.

The water, ash, lipid, protein, and crude fiber contents of the starch were determined according to the methods of the AOAC (2005) to evaluate purity. 


\section{Starch modification}

The starch was modified via phosphorylation using STP (Prolab, São Paulo, Brazil). The experiment followed a randomized double $2 \mathrm{x}$ 2 factorial design with additional treatment, in 4 replicates. The factors were STP solution in concentrations of 3 and $7 \mathrm{~g}$ of salt in $100 \mathrm{~mL}$ of water and an esterification time $(\theta)$ of 30 and 50 minutes. The additional treatment was native starch (SBNS), used as a control in the experimental design. The combination of the factor levels and their respective names are shown in Table 1. The response variable for this experiment was the percentage of phosphorus $(\% \mathrm{P})$ contained in the various starches that were studied.

Table 1. Phosphorus content [P $\left.\left(\mathrm{g} 100 \mathrm{~g}^{-1}\right)\right]$ of the Swartzia burchelli native starch (SBNS) and phosphated starches according to the sodium tripolyphosphate (STP) concentration and esterification time $(\theta)^{1}$.

\begin{tabular}{lccc}
\hline Treatment & STP $(\%)$ & $\theta(\min )$ & $\mathrm{P}\left(\mathrm{g} 100 \mathrm{~g}^{-1}\right)$ \\
\hline SBNS & - & - & $0.129 \pm 0.001$ \\
S3T30 & 3 & 30 & $0.160 \pm 0.002 * \mathrm{c}$ \\
S3T50 & 3 & 50 & $0.181 \pm 0.00 *^{*} \mathrm{c}$ \\
S7T30 & 7 & 30 & $0.247 \pm 0.005 * \mathrm{~b}$ \\
S7T50 & 7 & 50 & $0.300 \pm 0.028 * \mathrm{a}$ \\
\hline
\end{tabular}

* Measurements that differ from the control $(\mathrm{p}=0.05)$ according to Dunnett's test.

STP $(\%)$ - amount of STP in $100 \mathrm{~g}$ of water (3 parts starch was modified in 5 parts STP solution).

Means followed by the same letter do not differ $(\mathrm{p}<0.06)$ according to Tukey's test.

- Not applied (control).

${ }^{1}$ Means of 4 replicates \pm standard deviation.

The chemical modification was conducted via esterification according to the method described by Paschall (1964), with modifications. Mixtures containing a proportion (w/v) of 3 parts SBNS in 5 parts STP (named SSTP) (Table 1) were stirred using a Fisaton mechanical shaker (713D, São Paulo, Brazil) at times pre-established in the factorial design. After stirring, the mixture was vacuum-filtered and dried in an oven at $45{ }^{\circ} \mathrm{C}$ for 48 hours. The dry matter was washed with ethyl alcohol (Synth, Diadema, Brazil) at $50 \mathrm{~g} 100 \mathrm{~g}^{-1}$ to remove the water residue; this procedure was repeated 2 more times. The resulting modified starch was dried again at $45^{\circ} \mathrm{C}$ for 48 hours.

The excess residual phosphorus salts contained in the modified starch were removed using dialysis. Aqueous suspensions of starch phosphates at 10 g $100 \mathrm{~g}^{-1}$ were placed on cellophane paper and immersed in distilled water for 7 days under refrigeration $\left( \pm 6{ }^{\circ} \mathrm{C}\right)$, and the distilled water was replaced daily. After dialysis, the starch phosphates were dried at $45{ }^{\circ} \mathrm{C}$ for 24 hours, sieved through a $150-\mu \mathrm{m}$ mesh sieve, and stored in a closed airtight polyethylene flask.

The phosphorus content $(\% \mathrm{P})$ of the native and modified starches was determined according to the technique described by Brasil (2008) using spectrophotometry in a SP-2000UV UV/Vis spectrophotometer (Biosystems, Barcelona, Spain) at $420 \mathrm{~nm}$.

\section{Preparation and characterization of the edible films}

The native and starch phosphates were used to prepare the edible films, which were statistically selected using the lower, intermediate, and higher phosphorus content criterion. A completely randomized 2 x 2 factorial design with 4 levels was adopted to study the effect of the factors, which included starch type [ST: SBNS and starch phosphates that were prepared based on 3,7 , and 7 parts STP using esterification times of 30, 30, and 50 minutes, named S3T30, S7T30, and S7T50, 
respectively, selected using the criterion previously described], and 4 glycerol concentrations (Vetec, Rio de Janeiro, Brazil) (GLY: 5, 10, 15, and 20\% for each selected starch). The analyzes were performed in triplicate, on the thickness, water vapor permeability (Wvp) and water solubility of the edible films.

The films were prepared using the spreading technique described by Yang and Paulson (2000), with modifications. In aqueous starch solution was added glycerol (in proportions pre-established in the experimental design), however, based on the weight of starch ( $\left.2 \mathrm{~g} 100 \mathrm{~g}^{-1} \mathrm{w} / \mathrm{v}\right)$. The solutions were heated until starch gelatinization $\left(80\right.$ to $95{ }^{\circ} \mathrm{C}$ for 2 to 3 minutes), producing the filmogenic solutions (FS). Subsequently, $20 \mathrm{~mL}$ of FS was transferred to a polyethylene Petri dish ( $9 \mathrm{~cm}$ diameter) and dried at $30 \pm 2{ }^{\circ} \mathrm{C}$ in a forced-air oven for 24 hours. Next, the films were removed from the Petri dishes for analysis.

Film thickness was measured using an external manual micrometer (Digimess, São Paulo, Brazil) with $0.001 \mathrm{~mm}$ accuracy, at ten different points, including 1 at the film center.

Wvp was gravimetrically determined at $25{ }^{\circ} \mathrm{C}$ according to the E96-80 method described by the American Society for Testing and Materials (ASTM, 1989), with modifications. The films were cut into circles and applied to adapted plastic permeation cells containing silica gel. The cells were placed in desiccators containing distilled water, and the set was stored at $25{ }^{\circ} \mathrm{C}$ in a biochemical oxygen demand (BOD) incubator (Lucadema, São Paulo, Brazil). The weight of the cell with the film was monitored at 24-hour intervals for 9 days using a BG400 analytical balance (Gehaka, São Paulo, Brazil) with $0.001 \mathrm{~g}$ accuracy. The Wvp rate was calculated using equation (1):

$$
\mathrm{Wvp}=\frac{\mathrm{g}}{\mathrm{t}^{*} \mathrm{~A}} \frac{\mathrm{x}}{\Delta \mathrm{P}}
$$

where $g$ is the weight gain in grams, $t^{*}$ is total time in hours, and $A$ is the permeation area in $\mathrm{m}^{2}$. The $g / t^{*}$ term was calculated by linear regression between the weight gain and time points, in steady state. The mean film thickness in $\mathrm{mm}$ is given by $x$, and $\Delta \mathrm{P}$ is the difference in vapor pressure of the silica gel- $(0$ $\mathrm{kPa}$, at $\left.25^{\circ} \mathrm{C}\right)$ and pure water- $\left(3.17 \mathrm{kPa}\right.$, at $\left.25^{\circ} \mathrm{C}\right)$ containing environment. The results are expressed in $\mathrm{g} \mathrm{mm} \mathrm{h}^{-1} \mathrm{~m}^{-2} \mathrm{kPa}^{-1}$.

Water solubility was determined according to Gontard et al. (1992). The known-moisture films were cut to $2 \mathrm{~cm}$ in width and weighed. The samples were individually placed in Erlenmeyer flasks containing $50 \mathrm{~mL}$ of distilled water and slowly stirred in a water bath shaker (Dubnoff, Piracicaba, Brazil) at $25^{\circ} \mathrm{C}$ for 24 hours. After this period, the samples were removed and dried in a forced-air oven at $105^{\circ} \mathrm{C}$ for 24 hours to determine the weight of the solubilized material. The solubility was calculated as:

$$
\% \mathrm{DW}=100\left(\frac{\mathrm{IW}-\mathrm{FW}}{\mathrm{IW}}\right)
$$

where $\% D W$ is the percentage of the solubilized dry matter, $I W$ is the initial weight of the dry matter and $F W$ is the final weight of the insolubilized dry matter.

Application of the edible coating to cherry tomatoes

Considering that permeability is an important parameter in measuring the quality of edible films, which are applied to dried products when they exhibit low permeability and to fresh products such as fruits and vegetables when they exhibit intermediate or high permeability (SOBRAL, 2000), the films containing low, intermediate, and high Wvp were chosen for preparation of the edible coating.

The weight loss (\%WL), soluble solids (SS), titratable acidity (TA), maturation index (MI), and 
firmness of the cherry tomatoes were determined in relation to edible coating type and shelf life.

A completely randomized $4 \times 8$ factorial design was used to combine days of analysis $(\theta \mathrm{v}: 0,3,6,9$, $12,15,18$, and 21 days) with the levels of coatings containing native starch with 5\% glycerol (SBNSC); modified starches S7T30 (SC7T30) and S7T50 (SC7T50) with 10 and 20\% glycerol, respectively; and no coating (control, NC). Three replicates were performed in each case. Each experimental plot contained 5 cherry tomatoes.

The edible coatings were prepared using the same technique applied to the previous filmogenic solutions, following Yang and Paulson (2000). Before application, the coatings were cooled to 40 ${ }^{\circ} \mathrm{C}$, and then the tomatoes were dipped for 5 minutes and suspended in a fine mesh sieve until the coating dried. This process was repeated 2 times. After the coatings were fixed and dried, the fruits were stored in a BOD incubator at $10 \pm 2{ }^{\circ} \mathrm{C}$ and a relative humidity of $80 \pm 5 \%$ for 21 days. The physicalchemical properties of the fruits were measured every 3 days.

Weight loss is expressed as a percent, using a Mark 500 analytical balance (Tepron, São Paulo, Brazil), with $0.001 \mathrm{~g}$ accuracy, according to the equation:

$$
\% \mathrm{WL}=100\left(\frac{\mathrm{w}_{0}-\mathrm{w}}{\mathrm{w}_{0}}\right)
$$

where $w_{0}$ is the initial weight of the sample $(\mathrm{g})$, and $w$ is the weight at every time interval $(\mathrm{g})$.

The SS, TA, and MI were determined according to the recommendations of Brasil (2008).

Fruit firmness was determined using a Brookfield texturometer (Texture analyzer CT3 $50 \mathrm{~K}$, Massachusetts, USA), at a penetration depth of $5 \mathrm{~mm}$ and a speed of $6.9 \mathrm{~mm} \mathrm{~s}^{-1}$. The results are expressed in centiNewtons $(\mathrm{cN})$.

\section{Statistical analysis}

The results obtained from the starch following modification were subjected to analysis of variance (ANOVA) at the $6 \%$ probability level to test for differences in phosphorus content according to SSTP concentration and phosphating time. Dunnett's test was applied at the same previous significance level to test for differences among the treatments due to the factorial scheme, and Tukey's test was applied to the factorial treatments at the previous probability level for analysis of the means. The latter test was used to select the phosphated starches used in film preparation.

The effects of coating and storage time on the post-harvest properties of the cherry tomatoes were evaluated by applying ANOVA to the weight loss, soluble solids/titratable acidity ratio (SS/TA), and firmness data. When the $\mathrm{C} \times \theta \mathrm{v}$ interaction was significant, Tukey's test was applied to the qualitative variable $\mathrm{C}$, and linear regression was applied to the quantitative variable $\theta \mathrm{v}$, at the $5 \%$ probability level.

All statistical analyses were performed in Statistica 8.0 (STATSOFT, 2007).

\section{Results and Discussion}

The $S$. burchelli native starch extracted under the conditions used in the present study exhibited low

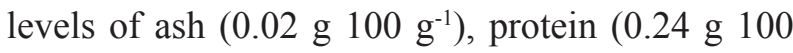

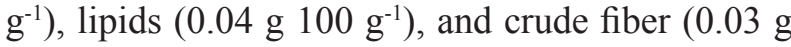
$\left.100 \mathrm{~g}^{-1}\right)$, as well as considerable phosphorus $(0.129$

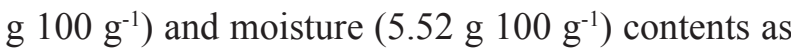
established by the Brazilian Legislation (BRASIL, 2005) for commercial starches. These factors combined, this starch can be characterized as goodquality for modification by phosphorylation.

After the native starch was phosphorylated, the phosphorus content increased with increasing STP and $\theta$ levels (Table 1). The lowest and highest phosphorus levels were observed in treatments

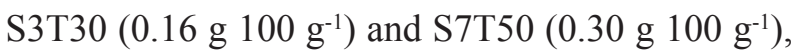
respectively. 
According to the ANOVA applied to the factorial scheme with additional treatment, interactions were recorded between $\mathrm{STP}$ and $\theta(\mathrm{F}=4.62 ; p=0.052)$ and the factorial and the control $(\mathrm{F}=164.25 ; p<$ $0.01)$, where the treatments were significantly different from the control (SBNS) according to Dunnett's test $(p<0.01)$, (Table 1). According to Tukey's test, no differences were detected between treatments S3T30 and S3T50, which exhibited a mean phosphorus content of $0.17 \%$. However, these treatments differed from treatments S7T30 and S7T50, which exhibited phosphorus levels of 0.247

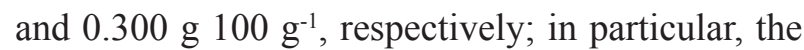
latter treatments were found to differ from each other. The differences in phosphorus levels between treatments S7T30 and S7T50 indicate that higher phosphorus inclusion into SBNS occurs at higher STP amounts and longer phosphating times.

The presence of phosphorus in the molecules is an important factor in the variation of the functional properties of the starches, including gelatinization and retrogradation (KARIM et al., 2007). The SBNS and treatments S3T30, S7T30, and S7T50 (selected from Table 1 for exhibiting low, intermediate, and high phosphorus content values, respectively) were used for preparation of the edible films. The responses of the water vapor permeability and water solubility index of the films were plotted (Figures 1 and 2).

Starch films are highly translucent, which is an essential characteristic with respect to improving the presentation of the coated fruits and increasing their attractiveness to consumers. This feature in itself adds value to the starch film-coated product because the film can be easily removed by rubbing or washing, thereby facilitating the cleaning process carried out by the end consumer (BESSA et al., 2015).

Based on the Wvp and water solubility index responses of the films obtained, an interaction was recorded between ST x GLY (Figures 1 and 2), i.e., the effect of glycerol level on the Wvp and solubility values of the films is affected by the starch type employed, and vice versa. The Wvp increased linearly $\left(\mathrm{R}^{2}=0.999\right)$ as a function of GLY in all studied starches. According to Matta Junior et al. (2011), this increase is due to the high affinity of glycerol for water, which confers higher flexibility properties to the films and thus leads to increased macromolecule mobility; as a result, the diffusion of water molecules through the edible films is facilitated (SARANTÓPOULOS et al., 2002; MARTELLI et al., 2006).

Figure 1. Water vapor permeability (Wvp) of the films prepared with native (SBNS) and phosphated starches (S3T30, S7T30, and S7T50) of $S$. burchelli according glycerol concentration and starch type.

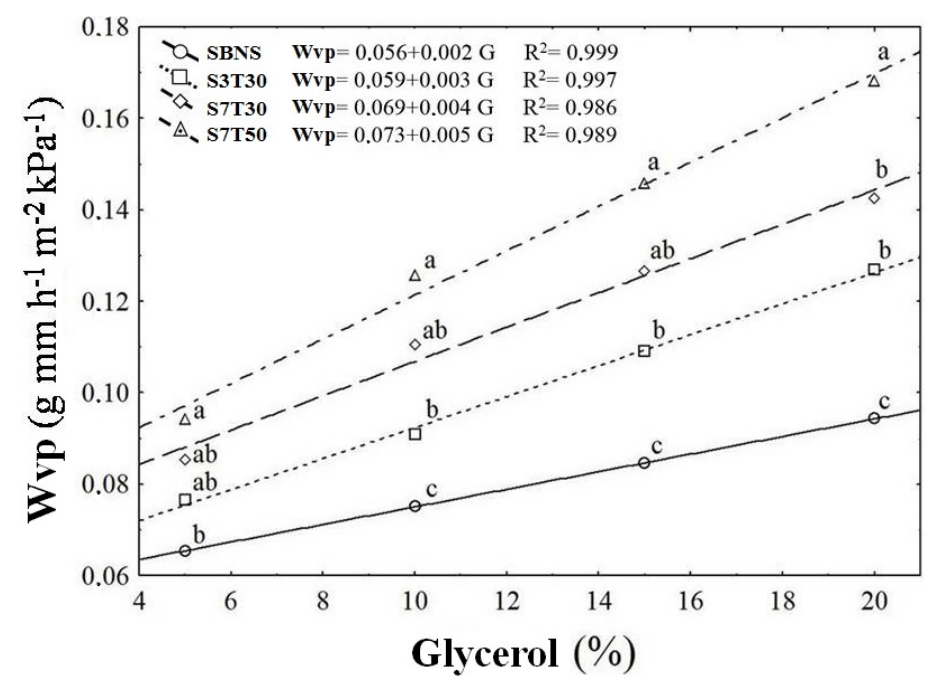

Means followed by the same letter vertically do not differ according to Tukey's test $(\mathrm{p}>0.06)$. 
Figure 2. Water solubility of the films prepared with $S$. burchelli native starch (SBNS) and phosphated starches (S3T30, S7T30, and S7T50) according to glycerol concentration and starch type.

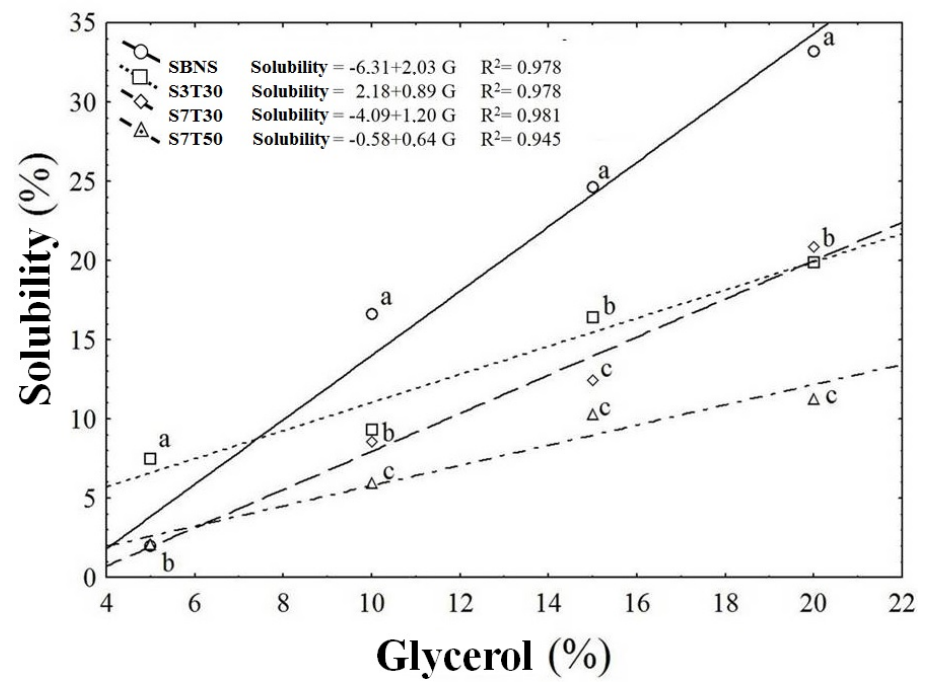

Means followed by the same letter vertically do not differ according to Tukey's test $(\mathrm{p}>0.06)$.

Starch type was found to affect the properties of the films based on the observation of different Wvp values; the significance of this observation was confirmed by Tukey's test (Figure 1). S7T50 formed films with higher permeability $(0.168 \pm 0.006 \mathrm{~g} \mathrm{~mm}$ $\left.\mathrm{h}^{-1} \mathrm{~m}^{-2} \mathrm{kPa}^{-1}\right)$ followed by S7T30, S7T30, and SBNS in decreasing order $(0.143 \pm 0.003,0.127 \pm 0.008$, and $0.094 \pm 0.009 \mathrm{~g} \mathrm{~mm} \mathrm{~h}^{-1} \mathrm{~m}^{-2} \mathrm{kPa}^{-1}$, respectively). This indicates that film permeability increases directly with longer starch phosphating time.

Except for the film prepared with S3T30 using $5 \%$ glycerol, all films were less soluble than those prepared with native starch (Figure 2). According to Tukey's test $(p<0.05)$, significantly higher differences in solubility were obtained at the $20 \%$ glycerol concentration. The highest and lowest solubility values were detected in the SBNS (33.17 g $100 \mathrm{~g}^{-1}$ ) and S7T50 films (11.25 g $\left.100 \mathrm{~g}^{-1}\right)$, respectively. Intermediate solubility values were

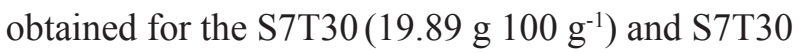

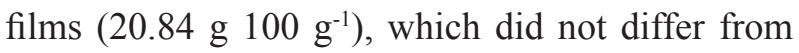
each other according to Tukey's test $(p<0.05)$ at the $20 \%$ glycerol concentration.
The ultimate selection criterion of the edible coatings for application to cherry tomato crops was the prepared film's water vapor permeability, where films that exhibited low (native starch with 5\% glycerol, CSBNS), intermediate (S7T30 with 10\% glycerol, SC7T30), and high permeability (S7T50 with 20\% glycerol, SC7T50) were applied and were compared against the control (no coating, NC).

Experimental data on weight loss (Figure 3), SS/TA ratio (Figure 4), and firmness (Figure 5) as a function of storage time were collected from the cherry tomatoes under the condition of with and without coating.

According to the ANOVA results, an interaction was recorded between the $\mathrm{C} x \theta \mathrm{v}$ factors $(p<0.01)$. These factors are dependent on each other, i.e., each weight loss, SS/TA, and firmness response was obtained based on combinations of the factor levels. In Table 2, by taking the time factor as fixed, significant differences were recorded in cherry tomato weight loss between each starch type after day 6 of storage; in contrast, for SS/TA and firmness, significant differences were detected over 
the complete storage time. By fixing the coating factor, time was found to affect the weight loss and firmness responses at all levels; in contrast, for the SS/TA response, no significant differences were observed between the SC7T30 and SC7T50 coatings.

Figure 3. Weight loss of the cherry tomatoes according to the coating type of $S$. burchelli native and phosphated starches and glycerol during storage.

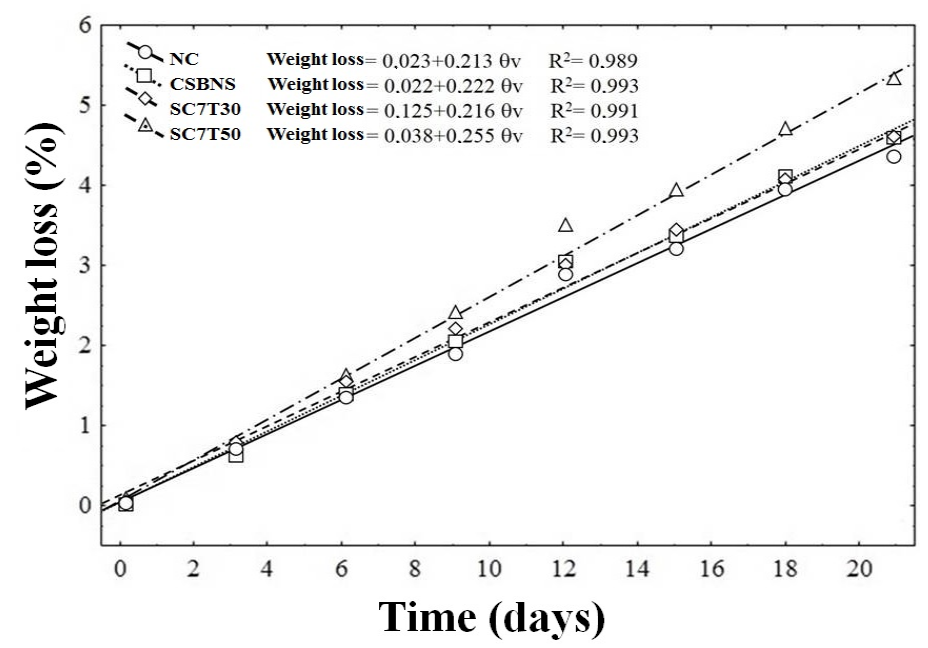

Table 2. Summary of the analysis of variance for the effect of the edible $S$. burchelli starch coating, glycerol, and storage time on the weight loss, SS/TA ratio, and firmness of the cherry tomatoes.

\begin{tabular}{llllllll}
\hline \multirow{2}{*}{ VF } & \multirow{2}{*}{ df } & \multicolumn{2}{l}{ Weight loss (\%) } & \multicolumn{3}{l}{ SS/TA } & \multicolumn{3}{l}{ Firmness } \\
\cline { 3 - 8 } & & SS & F & SS & F & SS & F \\
\hline Time $(\mathrm{t})$ & 7 & 33.45 & $3812.26^{* *}$ & $4.13 \mathrm{E}-03$ & $60.2^{* *}$ & 5691.5 & $1028.3^{* *}$ \\
C: 1 days & 3 & 0.00 & $0.00^{\text {ns }}$ & $7.20 \mathrm{E}-03$ & $105.0^{* *}$ & 3002.2 & $542.4^{* *}$ \\
C: 3 days & 3 & 0.02 & $1.88^{\text {ns }}$ & $4.71 \mathrm{E}-03$ & $68.7^{* *}$ & 1310.2 & $236.7^{* *}$ \\
C: 6 days & 3 & 0.04 & $4.77^{*}$ & $3.75 \mathrm{E}-03$ & $54.6^{* *}$ & 1204.3 & $217.6^{* *}$ \\
C: 9 days & 3 & 0.10 & $11.77^{* *}$ & $3.64 \mathrm{E}-03$ & $53.0^{* *}$ & 1990.0 & $359.5^{* *}$ \\
C: 12 days & 3 & 0.19 & $21.61^{* *}$ & $3.07 \mathrm{E}-03$ & $44.8^{* *}$ & 2990.3 & $540.3^{* *}$ \\
C: 15 days & 3 & 0.26 & $29.98^{* *}$ & $8.51 \mathrm{E}-03$ & $124.1^{* *}$ & 4464.3 & $806.6^{* *}$ \\
C: 18 days & 3 & 0.30 & $34.66^{* *}$ & $1.22 \mathrm{E}-02$ & $178.2^{* *}$ & 6415.9 & $1159.2^{* *}$ \\
C: 21 days & 3 & 0.49 & $55.83^{* *}$ & $1.92 \mathrm{E}-02$ & $280.3^{* *}$ & 7547.8 & $1363.7^{* *}$ \\
Cover $(\mathrm{C})$ & 3 & 0.95 & $108.67^{* *}$ & $2.57 \mathrm{E}-02$ & $374.4^{* *}$ & 16145.7 & $2917.1^{* *}$ \\
Time: $\mathrm{NC}$ & 7 & 7.36 & $839.25^{* *}$ & $1.93 \mathrm{E}-02$ & $281.7^{* *}$ & 13380.0 & $2417.4^{* *}$ \\
Time: $\mathrm{C}_{1}$ & 7 & 8.05 & $917.46^{* *}$ & $3.41 \mathrm{E}-04$ & $5.0^{* *}$ & 2771.1 & $500.7^{* *}$ \\
Time: $\mathrm{C}_{2}$ & 7 & 7.64 & $870.31^{* *}$ & $9.25 \mathrm{E}-05$ & $1.3^{\text {ns }}$ & 1179.5 & $213.1^{* *}$ \\
Time: $\mathrm{C}_{3}$ & 7 & 10.59 & $1207.46^{* *}$ & $8.10 \mathrm{E}-05$ & $1.2^{\text {ns }}$ & 340.8 & $61.6^{* *}$ \\
$\mathrm{t} x \mathrm{C}$ & 21 & 0.06 & $7.41^{* *}$ & $5.23 \mathrm{E}-03$ & $76.3^{* *}$ & 854.9 & $154.5^{* *}$ \\
Error & 64 & 0.01 & - & $6.86 \mathrm{E}-05$ & - & 5.5 & - \\
\hline
\end{tabular}

*Significant at the $5 \%$ probability level; ${ }^{\text {ns }}$ not significant.

VF- variation factor; df- degrees of freedom; SS- sum of squares; F- calculated. 
According to Figure 3, weight losses were observed over the course of the storage time, most likely as a result of the advanced maturation stage of the fruits following harvest, which accelerated their loss of moisture content due to transpiration. The highest weight loss was observed for the SC7T50 coating. The other treatments did not differ from the control. Thus, the edible coatings were insufficient for reducing the weight loss of the fruits in relation to post-harvest storage. This finding may be due to the hydrophilicity of glycerol (MALI et al., 2004), such that the coating with the highest glycerol percentage (SC7T50) led to higher weight loss compared to the other coatings; if the coating failed to form an effective control barrier to reduce fruit transpiration, weight loss would have been the direct result. According to Park et al. (2005), these results are expected when using polysaccharidebased materials, which are unable to act as a barrier against the loss of moisture content, likely increasing product weight loss and necessitating the addition of lipid compounds.

Although the tomato, as a species, stores very little starch, small increments in the SS content were observed in accordance with storage time, with a significant $(p<0.01)$ variation observed in the $\mathrm{SS} /$ TA ratio as a function of this factor (Figure 4). The increase in the soluble solids content throughout storage is due to the degradation of polysaccharides during fruit respiration (CHITARRA; CHITARRA, 2005) and to the accumulation of these solids due to the observed loss of moisture content (LEMOS et al., 2007). The SS/TA ratio was 0.81 at the onset of the experiment and 0.89 at the end of the storage period. Sousa et al. (2011) analyzed the maturation index in cherry tomato and observed a mean value of 3.88, which was higher than that observed in this study. This low maturation index is related to the low and high soluble solids and titratable acidity values, respectively, observed during storage.

Figure 4. Maturation index (SS/TA) of the cherry tomatoes according to the coating type of S. burchelli native and phosphated starches and glycerol during storage.

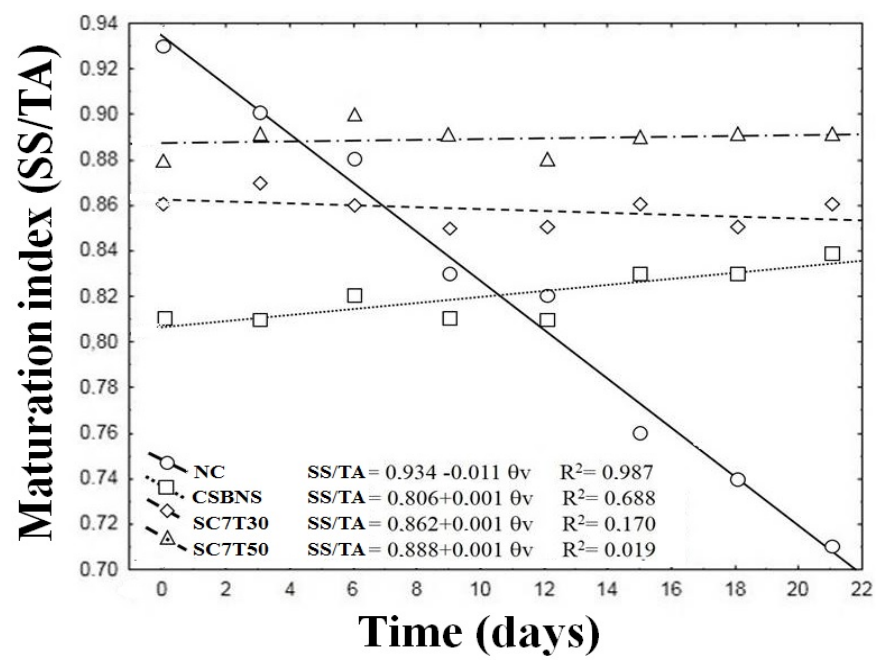

In a study conducted by León-Sánchez et al. (2009) with tomatoes stored at 10 and $20^{\circ} \mathrm{C}$ for 20 days, the fruit stored at $10^{\circ} \mathrm{C}$ showed no changes in firmness and exhibited slowing enzymatic activity. The same was observed in the present experiment
(Figure 5), in which the fruits coated with filmogenic solutions exhibited slight decreases in firmness during storage, whereas the uncoated control fruits exhibited a significant decrease in firmness. 
Figure 5. Firmness of the cherry tomatoes according to the coating type of $S$. burchelli native and phosphated starches and glycerol during storage.

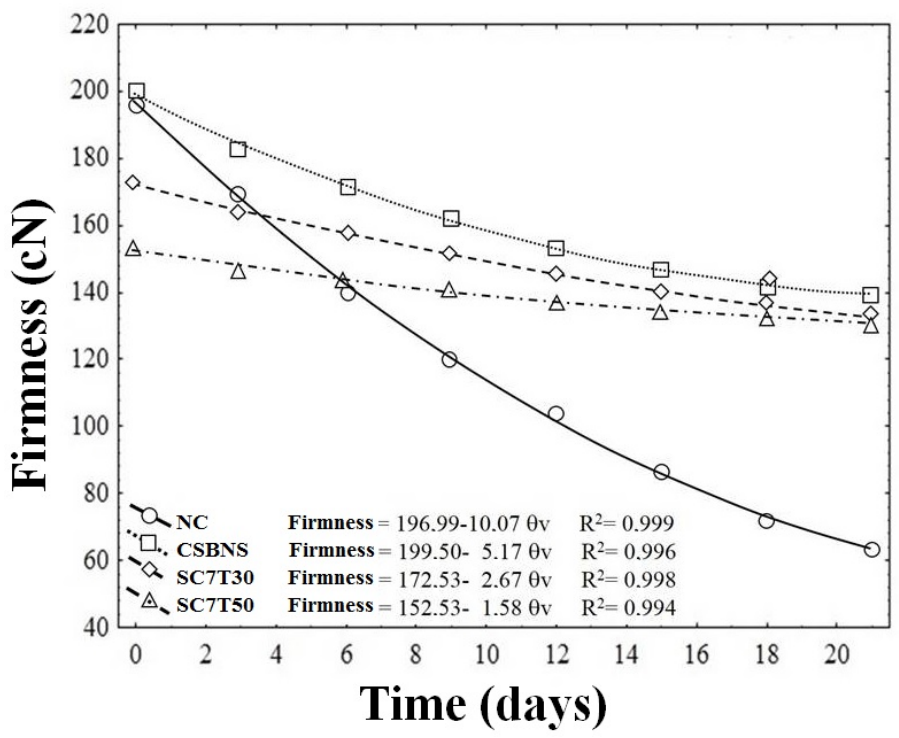

The same was observed by Bessa et al. (2015), who evaluated guavas with edible coatings of corn starch and sorbitol as a plasticizer, at a temperature of $\pm 22{ }^{\circ} \mathrm{C}$, and reported that during the storage time, guava firmness decreased more pronouncedly in the uncoated fruits. Because edible coatings form a protective barrier that surrounds the fruit, they most likely hindered the entry of $\mathrm{O}_{2}$ and exit of $\mathrm{CO}_{2}$, thus reducing metabolism and hydrolytic enzyme activity, which promotes solubilization of the pectic substances of the cell wall and causes a decrease in fruit softening, consequently maintaining the fruit's firmness (FERREIRA et al., 2010).

\section{Conclusions}

The increase in phosphorus content in the $S$. burchelli modified starches for all treatments led to an increase in water vapor permeability and a decrease in the solubility of the edible films. The variation in glycerol concentration affected the properties of the prepared films: both water vapor permeability and water solubility were found to increase with plasticizer content, thereby improving the characteristics of the films and enhancing their post-harvest utility.

The edible coating of $S$. burchelli made the cherry tomatoes visually more attractive because the fruits remained bright in color and the films were clear, thereby enhancing the overall appearance of the fruit. The coatings with higher Wvp (phosphated

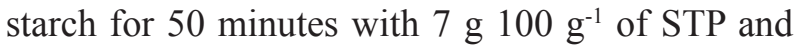
$20 \%$ of glycerol) maintained the maturation index and firmness during the experimental period and provided better post-harvest storage conditions. Thus, films and edible coatings of $S$. burchelli are recommended for the protection and visual enhancement of coated fruit products.

\section{Acknowledgements}

The authors appreciate the scholarship granted by the Researcher Program of the State University of Goiás (BIP) and by the Coordination for the Improvement of Higher Education Personnel (CAPES), as well as the financial supported granted by the Research Foundation of the State of Goiás (FAPEG). 


\section{References}

ALBERTI, M. L.; SOUZA, S. J.; GONÇALVES, H.; YAMASHITA, F.; SHIRAI, M. A. Efeito da adição de quitosana em laminados de amido e poli(ácido lático) produzidos por extrusão. Revista Brasileira de Pesquisa em Alimentos, Guarapuava, v. 6, n. 1, p. 80-90, 2015.

ALVES, A. I.; SARAIVA, S. H.; LUCIA, S. M. D.; TEIXEIRA, L. J. Q.; JUNQUEIRA, M. S. Qualidade de morangos envolvidos com revestimento comestível antimicrobiano à base de diferentes fontes de amido. Enciclopédia Biosfera, Goiânia, v. 7, n. 13, p. 15191525, 2011.

ASSOTIATION OF OFFICIAL ANALYTICAL CHEMISTS - AOAC. Official methods of analysis of AOAC. $18^{\text {th }}$ ed. Washington: AOAC, 2005.

AMERICAN SOCIETY FOR TESTING AND MATERIALS - ASTM. Standard test methods for water vapor transmission of materials (E96-80) In:

Annual book of ASTAM standards. Philadelphia: ASTM, 1989. p. 730-739.

BERGO, P.; SOBRAL, P. J. A.; PRISON, J. M. Effect of glycerol on physical properties of cassava starch films. Journal of Food Processing and Preservation, Malden, v. 34, n. 2, p. 401-410, 2010.

BESSA, R. A.; OLIVEIRA, L. H.; ARRAES, D. A.; BATISTA, E. S.; NOGUEIRA, D. H.; SILVA, M. S.; RAMOS, P. H.; LOIOLA, A. R. Filmes de amido e de amido/zeólita aplicados no recobrimento e conservação de goiaba (Psidium guajava). Revista Virtual Química, São Paulo, v. 7, n. 6, p. 2190-2201, 2015. Disponível em: $\quad<$ http://www.uff.br/RVQ/index.php/rvq/article/ viewArticle/1058>. Acesso em: 3 dez. 2015.

BOURTOOM, T. Edible films and coatings: characteristics and properties. International Food Research Journal, Selangor, v. 15, n. 3, p. 237-248, 2008.

BRASIL. Instituto Adolfo Lutz. Secretaria de Estado da Saúde. Métodos físico-químicos para análise de alimentos. 4. ed. São Paulo: Instituto Adolfo Lutz, 2008. cap. 15 , p. $579-586$.

Agencia Nacional de Vigilância Sanitária do Ministério da Saúde. Resolução RDC n. 263 de 22 de setembro de 2005 da Agencia Nacional de Vigilância Sanitária do Ministério da Saúde. Regulamento Técnico para Produtos de Cereais, Amidos, Farinhas e Farelos. Diário Oficial [da] República Federativa do Brasil, Brasília, 23 set. 2005. Seção 1, p. 368-369.

CHITARRA, M. I. F.; CHITARRA, A. B. Pós-colheita de frutos e hortaliças: fisiologia e manuseio. 2. ed. Lavras: UFLA, 2005. $785 \mathrm{p}$.
DHANAPAL, A.; SASIKALA, P.; RAJAMANI, L.; KAVITHA, V.; YAZHINI, G.; BANU, M. S. Edible films from Polysaccharides. Food Science and Quality Management, Kusami, v. 3, p. 9-17, 2012.

FERREIRA, S. M. R.; QUADROS, D. A.; KARKLE, E. N. L.; LIMA, J. J.; TULLIO, L. T.; FREITAS, R. J. S. Qualidade pós-colheita do tomate de mesa convencional e orgânico. Ciência e Tecnologia de Alimentos, Campinas, v. 30, n. 4, p. 858-864, 2010.

GONTARD, N.; GUILBERT, S.; CUQ, J. L. Edible wheat gluten films - influence of the main process variables on film properties using response surface methodology. Journal of Food Science, Chicago, v. 57, n. 1, p. 190195, 1992.

HENRIQUE, C. M.; CEREDA, M. P.; SARMENTO, S. B. S. Características físicas de filmes biodegradáveis produzidos a partir de amidos modificados de mandioca. Ciência e Tecnologia de Alimentos, Campinas, v. 28, n. 1, p. 231-240, 2008.

KARIM, A. A.; TOON, L. C.; LEE, V. P.; ONG, W. Y; FAZILAH, A.; NODA, T. Effects of phosphorus contents on the gelatinization and retrogradation of potato starch. Journal of Food Science, Chicago, v. 72, n. 2, p. C132-C138, 2007.

KASIRAJAN, S.; NGOUAJIO, M. Polyethylene and biodegradable mulches for agricultural applications: a review. Agronomy for Sustainable Development, Paris, v. 32, n. 2, p. 501-529, 2012.

KHWALDIA, K.; ARAB-TEHRANY, E.; DESOBRY, $\mathrm{S}$. Biopolymer coatings on paper packaging materials. Comprehensive Reviews in Food Science and Food Safety, Chicago, v. 9, n. 1, p. 82-91, 2010.

LATNER, K.; O'KRAY, C.; JIANG, J. China, peoples republic of bio-fuels an alternative future for agriculture 2006. USA: USDA Foreign Agricultural Service. Global Agriculture Information Network (GAIN), Report Number: CH6049. USDA, 2006. 14 p.

LEMOS, O. L.; REBOUÇAS, T. N. H.; SÃO JOSÉ, A. R.; VILA, M. T. R.; SILVA, K. S. Utilização de biofilme comestível na conservação de pimentão 'Magali R' em duas condições de armazenamento. Bragantia, Campinas, v. 66, n. 4, p. 693-699, 2007.

LEÓN-SÁNCHEZ， F. D.; PELAYO-ZALDÍVAR, C.; RIVERA-CABRERA, F.; PONCE-VALADEZ, M.; ÁVILA-ALEJANDRE, X.; FERNÁNDEZ, F. J.; ESCALONA-NUENDÍA, H. B.; PÉREZ-FLORES, L. J. Effect of refrigerated storage on aroma and alcohol dehydrogenase activity in tomato fruit. Postharvest Biology and Technology, Amsterdam, v. 54, n. 2, p. 93100, 2009. 
MALI, S.; GROSSMANN, M. V. E.; GARCÍA, M. A.; MARTINO, M. M.; ZARITZKY, N. E. Barrier, mechanical and optical properties of plasticized yam starch films. Carbohydrate Polymers, Barking, v. 56, n. 2, p. 129-135, 2004.

MANSANO, V. F.; LEWIS, G. P.; TOZZI, A. M. G. A. Swartzia burchelli (Leguminosae- Papilionoideae) 20 from Goiás, Brazil; a new name for a taxon proposed by Bentham. Kew Bulletin, Londres, v. 57, n. 3, p. 635-638, 2002.

MARTELLI, S. M.; MOORE, G.; PAES, S. S.; GANDOLFO, C.; LAURINDO, J. B. Influence of plasticizers on the water sorption isotherms and water vapor permeability of chicken feather keratin films. $L W T$ Food Science and Technology, Zurich, v. 39, n. 3, p. 292301, 2006.

MATTA JUNIOR, M. D.; SARMENTO, S. B. S.; SARANTÓPOULOS, C. I. G. L.; ZOCCHI, S. S. Propriedades de barreira e solubilidade de filmes de amido de ervilha associado com goma xantana e glicerol. Revista Polímeros, São Carlos, v. 21, n. 1, p. 67-72, 2011.

MOJOVIĆ, L.; NIKOLIĆ, S.; RAKIN, M.; VUKASINOVIĆ, M. Production of bioethanol from corn meal hydrolyzates, Fuel, London, v. 85, n. 12-13, p. 1720-1755, 2006.

PARK, S. I.; STAN, S. D.; DAESCHEL, M. A.; ZHAO, Y. Antifungal coatings on fresh strawberries (Fragaria $\times$ ananassa) to control mold growth during cold storage. Journal of Food Science, Chicago, v. 70, n. 4, p. 202207, 2005.

PASCHALL, E. F. Phosphation with organic phosphate salts. In: WHIISTLER, R. E. L. (Ed.). Methods in carbohydrate chemistry. New York: Academic Press, 1964. v. 4, p. 294-296.
PRIELER, S.; FISCHER, G. Agricultural by-products associated with biofuel production chains. Report D5.1, Laxenburg: Elobio, 2009. 14 p. Disponível em: $<$ http://www.elobio.eu/fileadmin/elobio/user/docs/ DeliverableE_5.1.pdf $>$. Acesso em: 10 mar. 2015.

SARANTÓPOULOS, C. I. G. L.; OLIVEIRA, L. M.; PADUlA, M.; COLTRO, L.; ALVES, R. M. V. O.; GARCIA, E. E. C. Embalagens plásticas flexíveis: principais polímeros e avaliação de propriedades. Campinas: CETEA/ITAL, 2002. 276 p.

SOBRAL, P. J. A. Influência da espessura de biofilmes feitos à base de proteínas miofibrilares sobre suas propriedades funcionais. Pesquisa Agropecuária Brasileira, Brasília, v. 35, n. 6, p. 1251-1259, 2000.

SOUSA, A. A.; GRIGIO, M. L.; NASCIMENTO, C. R.; SILVA, A. C. D.; REGO, E. R.; REGO, M. M. Caracterização química e física de frutos de diferentes acessos de tomateiro em casa de vegetação. Revista Agro@mbiente On-line, Boa Vista, v. 5, n. 2, p. 113-118, 2011.

THE CREATORS OF ESTATISTICA - STATSOFT. Statistica (data analysis software system). Version 8.0. Tulsa: StatSoft, 2007. CD-ROM.

VICENTINO, S. L.; FLORIANO, P. A.; DRAGUNSKI, D. C.; CAETANO, J. Filmes de amidos de mandioca modificados para recobrimento e conservação de uvas. Química Nova, São Paulo, v. 34, n. 8, p. 1309-1314, 2011.

YANG, L.; PAULSON, A. T. Mechanical and water vapour barrier properties of edible gellan films. Food Research Internacional, Amsterdam, v. 33, n. 7, p. 563570, 2000. 
